\title{
Opmerkelijk
}

\section{Gehechtheidsstoornissen: Voor en na DSM-5}

Hoewel de term "attachment disorder" al voorkwam in de DSM-III, bleef de wetenschappelijke interesse voor deze stoornis gedurende de daaropvolgende 20 jaar beperkt. Bijgevolg werd de herziening van de criteria in latere versies van de geldende classificatiesystemen gedaan zonder beroep te kunnen doen op relevant onderzoek (Zeanah, 1996). In de laatste 15 jaar is het systematisch onderzoek naar gehechtheidsstoornissen echter toegenomen, wat heeft geleid tot fundamentele veranderingen in de DSM-5. De belangrijkste verandering heeft betrekking op de presentatie van de twee verschijningsvormen.

\section{Twee stoornissen in plaats van één}

De DSM-IV en de ICD-10 beschreven vergelijkbare kenmerken van gehechtheidsstoornissen, namelijk het voorkomen van onaangepast sociaal gedrag in verschillende situaties dat veroorzaakt werd door ernstig ontoereikende verzorging en opvoeding. Daarnaast erkenden beide classificatiesystemen de twee klinische fenotypes van geremd, emotioneel teruggetrokken gedrag en sociaal ontremd gedrag. Ondanks de algemene overeenkomsten in de criteria verschilden deze diagnostische systemen in de manier waarop ze de fenotypes presenteerden. De ICD-10 onderscheidde beide fenotypes als twee afzonderlijke stoornissen, terwijl de DSM-IV ze als subtypes van eenzelfde stoornis omschreef. De presentatie in de DSM-IV had volgens Zeanah en Gleason (2015) onder meer te maken met de veronderstelling dat beide fenotypes een gebrek aan gehechtheid beschreven bij kinderen die ontoereikende verzorging en opvoeding hadden ervaren; kinderen met het eerstgenoemde type vertoonden geen gehechtheidsgedragingen en kinderen met het andere type vertoonden niet-selectieve gehechtheidsgedragingen. Recent onderzoek wijst echter uit dat beide stoornissen sterk verschillen wat betreft hun kenmerken, correlaten, verloop, comorbiditeit met andere psychiatrische stoornissen en reactie op interventie. Bijgevolg beschreef de DSM-5 ze analoog aan de ICD-10 als twee afzonderlijke stoornissen (American Psychiatric Association, 2013).

\section{Reactieve hechtingsstoornis}

In tegenstelling tot eerdere beschrijvingen ligt de nadruk van de criteria voor reactieve hechtingsstoornis in de DSM-5 meer op afwezige of afwijkende gehechtheidsgedragingen in verschillende situaties dan op meer algemeen sociaal gedrag (Zeanah \& Gleason, 2015). Verschillende 
studies toonden immers aan dat de kern van deze stoornis te maken heeft met een tekort aan gehechtheidsgedragingen. Dit tekort uit zich enerzijds in het zelden of nauwelijks troost zoeken bij volwassen verzorgers of zelden of nauwelijks reageren op troost, als het kind van streek is. Anderzijds vertonen kinderen met een reactieve hechtingsstoornis minimale sociale en emotionele responsiviteit op anderen, een beperkt positief affect en/of episoden van onverklaarbare prikkelbaarheid, verdrietigheid of angstigheid die zelfs voorkomen in niet-bedreigende interacties (American Psychiatric Association, 2013).

\section{Ontremd-sociaalcontactstoornis}

Systematisch onderzoek naar gehechtheidsstoornissen heeft uitgewezen dat niet-selectieve gehechtheidsgedragingen niet de kern vormen van het sociaal ontremde subtype, maar wel het ongeregeld, onwillekeurig sociaal gedrag van deze kinderen, met name in interactie met onbekende volwassenen (Zeanah \& Gleason, 2015). Dit gaf aanleiding tot de naamswijziging in de DSM-5, waardoor de nadruk meer ligt op niet-selectieve vriendelijkheid ("indiscriminate friendliness") als kernsymptoom van de stoornis en minder op verstoord gehechtheidsgedrag, zoals bij de reactieve hechtingsstoornis. Kinderen met een ontremd-sociaalcontactstoornis tonen immers weinig tot geen terughoudendheid in de omgang met onbekende volwassenen, laten overmatig familiair verbaal of lichamelijk gedrag zien, houden hun volwassen verzorger weinig tot niet in de gaten bij verkenning van (zelfs onbekende) omgevingen en/of aarzelen weinig of niet om met een onbekende volwassene mee te gaan (American Psychiatric Association, 2013). Volgens Zeanah en Gleason (2015) blijft er echter discussie bestaan over de vraag waarom deze kinderen dergelijk ontremd sociaal gedrag stellen: worden ze gedreven door gehechtheid of door een ander doel?

\section{Pathogene of ontoereikende verzorging en opvoeding?}

Voor beide stoornissen bleven de criteria van extreme, problematische vormen van verzorging en opvoeding, als vermoedelijke oorzaak van het verstoorde gedrag, behouden in de DSM-5, weliswaar in licht gewijzigde vorm. Terwijl de DSM-IV nog verwees naar "pathogene" verzorging en opvoeding, heeft de DSM-5 het over "ontoereikende" verzorging en opvoeding. Daardoor komt de nadruk op sociale verwaarlozing als belangrijkste oorzaak van de stoornissen te liggen (Zeanah \& Gleason, 2015). Aangezien er nog geen evidentie bestond waaruit bleek dat één van beide stoornissen vaker tot uiting kwam bij een specifieke vorm van ontoereikende verzorging en opvoeding, bleef de beschrijving ervan voor beide stoornissen hetzelfde. In beide gevallen is er met andere woorden sprake van een voorgeschiedenis bestaande uit sociale verwaarlozing of deprivatie, herhaaldelijk wisselen van 
primaire verzorgers of opgroeien in ongebruikelijke omgevingen, waardoor de vorming van stabiele of selectieve gehechtheidsrelaties bemoeilijkt werd (American Psychiatric Association, 2013).

\section{Exclusie of comorbiditeit?}

Ondanks kritiek bleef het DSM-IV criterium dat kinderen die voldoen aan de criteria voor een autismespectrumstoornis uitgesloten worden voor een diagnose reactieve hechtingsstoornis, behouden in de DSM-5. De reden hiervoor was tweeledig: ten eerste bestond er nog geen onderzoek naar mogelijke comorbiditeit van beide stoornissen en ten tweede wilde men diagnostische verwarring voorkomen (Zeanah \& Gleason, 2010).

Voor de ontremd-sociaalcontactstoornis verwijst de DSM-5 niet naar uitsluiting van een andere stoornis, maar mag het verstoord gedrag zich niet beperken tot impulsiviteit, zoals bij de aandachtsdeficiëntie-/hyperactiviteitsstoornis (ADHD; American Psychiatric Association, 2013). Onderzoek toonde immers aan dat symptomen van ADHD en ontremd-sociaalcontactstoornis kunnen overlappen, waardoor exclusie van ADHD minder zinvol leek dan aandacht te vestigen op de manier waarop beide stoornissen zich van elkaar onderscheiden (Zeanah \& Gleason, 2015).

Bijkomend stelt de DSM-5 dat kinderen met een reactieve hechtingsstoornis of ontremdsociaalcontactstoornis een ontwikkelingsniveau van minstens negen maanden moeten hebben, zodat zij in staat zijn om een selectieve gehechtheidsrelatie aan te gaan (American Psychiatric Association, 2013). Desalniettemin lijkt verder onderzoek naar het nut van exclusiecriteria dan wel de mogelijkheid van comorbiditeit met andere stoornissen in het geval van de reactieve hechtingsstoornis of de ontremd-sociaalcontactstoornis aangewezen.

\section{Tot slot}

Wat deze veranderingen met zich meebrengen voor de klinische praktijk is nog niet duidelijk. Het onderscheid tussen beide stoornissen impliceert in ieder geval dat kinderen die sociaal ontremd gedrag vertonen als gevolg van ontoereikende verzorging en opvoeding, niet meer de diagnose gehechtheidsstoornis krijgen, zoals voorheen wel het geval was. De vraag is of de term "ontremdsociaalcontactstoornis" reeds haar weg gevonden heeft naar de diagnostische praktijk en of dit invloed heeft op de manier waarop clinici, leerkrachten, opvoeders of verzorgers met dit gedrag omgaan. Verschillende vragen blijven alleszins nog onbeantwoord, in het bijzonder vragen naar geschikte interventies. 


\section{Literatuur}

American Psychiatric Association (2015). Handboek voor de classificatie van psychische stoornissen (DSM-5). Nederlandse vertaling van Diagnostic and statistical manual of mental disorders, 5th edition. Amsterdam: Boom Psychologie \& Psychiatrie.

Zeanah, C.H. (1996). Beyond insecurity: A reconceptualization of attachment disorders in infancy. Journal of Consulting and Clinical Psychology, 64, 42-52.

Zeanah, C.H., \& Gleason, M.M. (2015). Annual Research Review: Attachment disorders in early childhood - clinical presentation, causes, correlates, and treatment. Journal of Child Psychology and Psychiatry, 56 (3), 207-222. 